\title{
LITERACIES AMONG YOUTH FROM \\ CAMPO (RURAL) COMMUNITIES: WHAT IS \\ REVEALED DURING VIDEO PRODUCTION
}

\author{
LETRAMENTOS DE JOVENS DO CAMPO: \\ O QUE SE REVELA NA PRODUÇÃO DE VÍDEOS
}

\author{
Maria Zélia Versiani Machado* \\ Gilcinei Teodoro Carvalho* \\ Carlos Augusto Novais ${ }^{* *}$ \\ Ana Paula da Silva Rodrigues ${ }^{\star \star \star \star}$
}

\begin{abstract}
This article presents the results of the research study, "Literacies in rural communities: social practices of reading and writing in school and non-school situations", conducted from 2015 to 2017. This study investigated how forms of sociability and communicative circuits in the daily lives of the rural youth constitute social practices of reading and writing. Initially, the use of the word "literacies" in the plural is justified. The context for this research is the Araçuaí Family Agroecological School in Vale do Jequitinhonha, Minas Gerais, Brazil. Analyses are based in the New Literacy Studies (STREET, 2014) and the methodology assumes a qualitative approach from an ethnographic perspective $\left(\mathrm{HEATH}_{i}\right.$ STREET, 2008) in which students collaborated in the production of videos with themes related to their communities. Video production was adopted as a methodological strategy to achieve literacies involved in the collective actions of the process. The results show that the use/non-use of digital technologies does not stand as a factor of differentiation between rural youth and urban youth, definitively breaking with the idea that rural communities are social spaces that lack literacy practices or that are disconnected from the virtual world, which shows that schools should broaden their concepts of literacy, not only by pluralizing practices, but mainly by incorporating them as a constitutive element of their teaching and learning project.
\end{abstract}

Keywords: literacies; rural education; rural youth; new technologies.

* Universidade Federal de Minas Gerais, UFMG, Belo Horizonte, MG, Brasil, zeliaversiani@gmail.com Orcid: https://orcid.org/0000-0002-6474-6966

** Universidade Federal de Minas Gerais, UFMG, Belo Horizonte, MG, Brasil, gilcineicarvalho@ gmail.com

Orcid: https://orcid.org/0000-0002-3137-5302

*** Universidade Federal de Minas Gerais, UFMG, Belo Horizonte, MG, Brasil, carlosanovais@ gmail.com.

Orcid: https://orcid.org/0000-0003-1224-1955

**** Instituto Federal de Minas Gerais, IFMG, Ribeirão das Neves, MG, Brasil, professoraanapaularodrigues@gmail.com.

Orcid: https://orcid.org/0000-0001-5345-9075

http://dx.doi.org/10.1590/010318135871115912020 


\section{RESUMO}

Este artigo apresenta resultados da pesquisa "Letramentos em comunidades rurais: práticas sociais de leitura e de escrita em situações escolares e não escolares", realizada de 2015 a 2017, que investigou como formas de sociabilidade e circuitos comunicativos presentes no cotidiano de jovens do campo constituem-se em práticas sociais de uso da leitura e de escrita. Inicialmente, justifica-se o uso da palavra letramentos no plural, e caracteriza-se o contexto da pesquisa, qual seja, a Escola Família Agroecológica de Araçuaí, no Vale do Jequitinhonha, em Minas Gerais, Brasil. As análises se apoiam nos Novos Estudos do Letramento (STREET, 2014) e a metodologia pressupõe uma abordagem qualitativa de perspectiva etnográfica $(H E A T H$, STREET, 2008) em que os estudantes foram colaboradores na produção de vídeos sobre temáticas relativas às suas comunidades. Adotou-se, assim, a produção de vídeos como estratégia metodológica para se chegar a letramentos envolvidos nas ações coletivas do processo. Os resultados apontaram que o uso/não uso das tecnologias digitais não se sustenta como um fator de diferenciação entre jovens do campo e jovens da cidade, rompendo definitivamente com a ideia de que as comunidades rurais são espaços sociais de ausência de práticas de letramento ou desconetadas do mundo virtual, o que evidencia que a escola deve ampliar os seus conceitos de letramento, não só pluralizando as práticas, mas, principalmente, incorporando-as como elemento constitutivo de seu projeto de ensino e de aprendizagem.

Palavras-chave: Letramentos, educação do campo, juventude rural, novas tecnologias.

\section{INTRODUCTION}

The title of this paper outlines two stances that hold political and pedagogic repercussions of great importance for the analysis presented here, as well as for the literacy field at large. The first stance is signaled by the use of the word literacies in the plural, suggesting that, though there is a hegemony of the single and universal concept of literacy that sees literacy as mainly associated with school practices, it is necessary to recognize literacy practices that expand into other spheres of human activity. The second stance is signaled by the use of the expression campo to refer to rural communities, a choice that requires an explanation before moving onto explaining how we see this term's political and educational implications. The terms campo and rural in a broad sense can refer to people who work and live in rural areas. However, locally, given the history of social movements for agrarian reform in Brazil the word campo often is used to refer to people who see themselves politically active in such social movements ${ }^{1}$. Such is the case of the students whose literacy practices are examined in this paper. The spatial indexing of the expression, campo, poses a contrast between literacy practices associated with urban life, that are also closely associated with the process of schooling in Brazil through historical

1. See MOLINA (2009) overview about the Brazilian political and historical foundations of Campo Education contrasting Rural Education. 
factors (e.g., limited schooling opportunities by virtue of the distance between rural communities and the schools' locations, which demands a student transport policy; limited availability of teachers trained to act in rural schools). This potential disassociation between "literacy" and "rural" constitutes a strong ideology that often turns reading and writing practices in campo social spaces invisible, especially when compared to more visible artifacts present in urban areas or institutions that stand out, such as in schools.

Interestingly, an international research agenda can be seen in relation to efforts to characterize 'rural literacy' (CORBETT; DONEHOWER, 2017). Green argues, for example, that "rural communities have been ill-served in the past by both a lack of research on rural literacy and by research and education initiatives that mischaracterize rural literacy" (DONEHOWER; HOGG; SCHELL, 2017 Apud GREEN, 2013, p.18). Little attention has been dedicated to research about rural literacy in Brazil. This theme tends to be featured only when systemic evaluations publish results and, therefore, list the performance of the rural schools as a possible factor for comparison or, worse, lamentation.

For this reason, the research presented here seeks to contribute to the modification of this image, reflecting from a conceptual and methodological standpoint on the literacy indexing elements that would justify a categorization of literacy practices based on a spatial category: urban/rural literacies. This position adds a deliberate social dimension to literacy, and we argue that the artifacts, forms of sociability, and communicative circuits present in daily life constitute social practices and socially valued uses of reading and writing.

Before we build a profile for this research's young student collaborators, although an immersion in this field of study is not the objective of the work, there is a need to make explicit the concept of "campo youth" with whom we are working and that is also signaled in the title. This concept is not definitively delimited in literature on this theme. When we use the expression "campo youth", and seek to conceptualize it, we perceive the challenge that is "naming these subjects without falling back to a traditional and stereotypical view of rural Brazil as a space limited to a non-urban perimeter" (LEÃO, ANTUNES-ROCHA, 2015, p. 21). This happens because there is no homogenous condition of rural youth in Brazil. According to the above authors,

We have young people who are in the campo, but live experiences and practices that are traditionally linked to urban spaces. On the other hand, many youths live in urban areas, but work in the campo. We can also find young people who were born and live in the campo, but do not wish to remain there, and young people from the city who move towards the campo 
in search for work and housing. (LEÃO, ANTUNES-ROCHA, 2015, p. 22. Translation by article's authors)

Another important aspect is that the distance between the campo and the city was narrowed by mobility options (the use of different means of transportation, such as motorcycles, for example) and communication (cellphone and internet), which favors a greater circulation of people and information between geographical and virtual spaces. This allows, in many cases, more identity proximity between young people of different geographical locations. This leads to some central questions that informed the study reported here: how do we differentiate the identities of campo youths? Can their literacy practices be identified and differentiated? Wouldn't the concept of "youth(s)" already encompass all the possible definitions for young people from different regions? Regarding the young subjects of this research, the complexity of the situation is no different.

This research study is a continuous of a larger project that has been running since 2012, starting with the Family Agricultural Schools (EFAs, from the Portuguese Escolas Familia Agrícola) of Minas Gerais. These school institutions were chosen as a gateway for reaching the research subjects and our subsequent insertion into some rural communities in the state of Minas Gerais. This choice is justified, in part, by the significant territorial dispersion of the state of Minas Gerais (MG), which would make a larger mapping more difficult, and, on the other hand, due our interest in examining school and non-school practices which meant we needed to be able to access participants in both contexts in a manageable and affordable way.

The initial research study, undertaken from 2012 to 2014², was carried out in an EFA from Zona da Mata/MG. Our observations identified a heterogeneity of school and non-school genres, signaling at times the presence of a pragmatic view relative to the world of labor expected for a context in which technical knowledge is desirable. At other times, we observed the influence of a reading canon that composes content and themes traditionally present in school contexts, both urban and rural. In this initial study - which counted on observations made in the school environment only; interviews with teachers, monitors and members of the administrative team; photographs of spaces and events; documents and records of academic and culture activities -, this included a mapping of views on reading and writing based on questionnaires filled out by the students. The presence of reading mediated by school parameters was found, especially through its professional character, as well as the process of schooling, which carries certain canonical values 
on what should be read. These values were indicated mainly by the naming, almost exclusively, of book titles considered to be literary classics, expressing a means of evidencing reading or knowledge or works valued by the school curriculum. The manner in which book culture still occupies a featured placement in the recognition of literacy practices considered authentic or legitimate was very much in evidence, even in schools found in the campo. In contrast, we found that the spheres of work and religion were predominant in non-school reading practices.

Following this initial research phase, diaries and interviews were adopted as methodological instruments in a subsequent phase (see recommendations in JONES; MARTIN-JONES; BHATT, 2012), which promoted a greater interaction of the youths in the context of their communities and overtly valued the students' voices. For the youths, the diaries constituted a personal routine mapping task, and at the same time, for the researchers, they represented a source for the elaboration of more qualified interviews, seeing as these written records were read beforehand, allowing for the definition of topics which would be better explored in face-to-face conversation. Two types of diaries were used; one to record activities developed at school and another for activities related to the time students spent in their originating communities, highlighting their work routines in domestic activities and involvement in sociocultural community practices permeated with literacy practices. The EFA alternates school time and community time - the students spend 15 days at school and 15 days in their communities - which allowed the diary writing methodology to cover both contexts for analysis of the literacies in either environment.

The later phase of this research project, reported in this article, was developed with the Family Agricultural School in Araçuai, Vale do Jequitinhonha, also in the state of Minas Gerais, Brazil. The choice of this institution maintained as criteria: a) the existence of an outreach project which had granted tablets to the EFA in the past ${ }^{3}$; b) the institution's adoption of the Alternation Pedagogy, characterized by integrating school and community; c) the relation between this school model and the Teacher Developing Program (Licenciatura em Educação do Campo, in Portuguese) where the participating professors and researchers work.

In this new research phase, seeking to expand our data collection methods in order to include campo youths more directly, participating students also were invited, as collaborators, to produce visual narratives about their communities

3. The project seeks to serve as an alternative to contribute to the academic development of young people in rural areas, through access to digital technology as a learning resource beyond those learned in the classroom. 
using short digital videos. This methodological approach sought to confront the dominating discourse which, very often, justified this audiovisual alternative as a device to soften challenges that would be identified in reading and writing processes, especially in situations which demanded a larger text with more authorship involvement, such as those that characterize the writing of diaries. In this manner, the videos were considered a language with great potential due to: (a) being closer to the youths' universe, at a time where sharing videos via YouTube is popular (b) being constituted by a language that theoretically wouldn't demand many contextualization processes, and, therefore, would fulfill the principle that "an image is worth more than a thousand words". With this in mind, our study didn't intend to make comparisons between a written production mode or an audiovisual mode, comparing diary writing with video production.

Beyond the video product, there was also a need to consider that the investigation had as an objective to identify the different literacies that campo youths participated in their video productions. For us, we assumed right from the start that the digital techniques incorporated in to their video making by the campo youths would amplify the concept of reading and writing by highlighting how language is multimodal. That is, we assumed reading and writing practices are made present in the process of audiovisual production, as well as in the final product.

We took a qualitative approach informed by an ethnographic perspective $\left(\mathrm{HEATH}_{i}\right.$ STREET, 2008), and the analyses focused on the concept of "literacies" developed by the New Literacy Studies, which conceives literacies as a social practice in a transcultural perspective, as proposed by Street (2014). The plural form is adopted to include different literacies, such as digital literacies, which are incorporated as a social practice - in the present study - by the youth population living in a rural context.

The video production method made possible the observation of the use of digital technology by the youths organized in groups, the knowledge that they mobilized for work organization and its execution, reading and writing practices involved in the process which included the choice of the theme, the video's structure as conveyed by the discussion of the script, the knowledge necessary for using the tablet, and editing processes, among other aspects.

Once the school was selected, several fieldwork observations were carried out at EFA Araçuaí (01 trip in 2015, 03 trips in 2016 and 02 in 2017) for in loco observation, with the intent to develop workshops - in a participant investigation perspective - for students regarding the use of the tablets accessed at school, accompanied by qualitative instruments such as questionnaires; interviews focused 
on the students' video production processes; testimonials from different subjects who operate in the EFA; photographic records of the space, its subjects and various activities related to the research, field activities that compose a mosaic of cultural and thematical references in the constitution of present literacy practices. Furthermore, the video production process allowed for the understanding, even if partial, of the students' rural communities of origin, both in terms of the cultural diversity that composes these rural communities and the social and environmental problems presented in the videos.

\section{WHERE THE YOUNG RESEARCH COLLABORATORS STUDY}

The Araçuai Family Agricultural School is located on the Calhauzinho Farm (Fazenda Calhauzinho), in the Barra do Córrego Narciso/Salitre community, in the Araçuaí municipality, in the Jequitinhonha Valley, in Minas Gerais. The school originates from the fight for the creation of an Environmental Preservation Area - "the cerrado" (APA, from the Portuguese Área de Preservação Ambiental) in the Lagoão Plateau (Chapada do Lagoão).

According to reports from students and monitors, the fauna and flora representative of the cerrado in this territory and the numerous lakes responsible for the springs that sustain neighboring communities alerted the population to the need to prevent eucalyptus monoculture and pastures from destroying the Plateau. Starting in 1978 onwards, and following many judicial processes, by 1991 the Plateau had become an Environmental Preservation Area of the municipality of Araçuaí.

Following this achievement, the population continued to mobilize with the intent to create a school which would prepare young people, encouraging them to preserve the region's diversity, and with scientific and practical knowledge based on quality schooling. From this perspective, 1997 saw some groundwork laid for mobilizing the community and gathering information about the Alternation Pedagogy, with the support of social, religious, and public power organizations at the time. During this process it was defined that the best location for the creation of the Agricultural Family School would be at the Barra do Córrego Narciso/ Salitre Community, due to it being located on the banks of the Calhauzinho Dam, which would provide better conditions for water availability for the agricultural and farming practices. This geographical location would allow the school to receive students from a larger number of cities. Groundwork for the construction of the 
EFA structure was developed for years and, in March 2009, the Araçuaí Family Agricultural School received its first class of students.

The school is managed by the County Association along with a director, monitors, employees and students. Its decisions go through all these spheres. Assemblies in which all students' parents are invited also occur.

At the time that the research was conducted, the school attended 120 students on average, distributed into three classes $\left(1^{\text {st }}, 2^{\text {nd }}\right.$, and $3^{\text {rd }}$ year of High School $)$ and gathered children of farmers from Araçuaí and neighboring municipalities, such as Caraí, Coronel Murta, Francisco Badaró, Itaipé, Jenipapo de Minas, Medina, and Virgem da Lapa. The students' commute every fifteen days (community-school/ school-community) were usually arranged with the support of the respective cities' town halls, Rural Work Union and other partners.

At the start of every school year, as part of orienting the new class, the youths go through an adaptation week in order to get to know the space, the school's daily activities, and the activities the students will be engaging in, among other fundamental procedures for the adaptation. During this week, the prospective students have the opportunity to familiarize themselves with the Alternation Pedagogy developed by the institution, which involves a two-week stay at the school (including meals and boarding) and two weeks at their place of origin, where they develop proposals for farming investigation and intervention, so as to favor the dialogue between traditionally rural and school knowledge, in particular due to the course offering technical training as a professional degree focus in this particular high school curriculum.

As such, the Araçuaí Family Agricultural School came to be from the demand of rural communities and social organizations that called for an education which would value agroecological practices and the knowledge and experience of the farmers. With the adoption of the Alternation Pedagogy, the school community is called to feature in a large part of the institution's structural actions, including its management. The families perceive the EFA as an opportunity for greater schooling, while it helps with generating income, without losing sight of the principles and values of the rural territory.

In the scope of the outreach project implemented by a federal institution, internet connection equipment was purchased and installed in 2014, in partnership with the Town Hall and Municipal Education Secretary of Araçuaí. The school currently boasts a computer lab and a wi-fi network installed on its dependencies, with its own regulations for students' use. 
Therefore, the EFA comprises an attractive space for campo youths, seeing that it places the student in a featuring role in an integrated formation educational project, and thereby promoting development in the environment in which they live. In this sense, the alternating boarding guarantees an integration between school, family, and work, and the EFA youths can build paths to remain in the campo with a strong quality of life, or to proceed with their studies according to their professional and academic ambitions.

\section{PROFILE OF THE STUDENTS OF THE ARAÇUAÍ FAMILY AGRICULTURAL SCHOOL}

The first research field trip occurred in July 2015. The EFA's relations with the Licenciatura em Educação do Campo (LeCampo) course at the originating institute of the researchers had been in construction since before this first trip. There was a preliminary contact with the students and school administration, which was possible due LeCampo students and alumni's work in the EFA, which also made technical visits and workshops possible, at the aforementioned EFA, during the Socioterritorial Journey promoted in Araçuaít.

The objective of this first trip was to further knowledge about the EFA, its students, its organization, and to present our research proposal to the school community. During this opportunity, we applied a questionnaire to the $1^{\text {st }}$ year high school students. The questionnaire sought to construct an initial profile of first year EFA students. Thirty-nine (39) students responded to our questionnaire. In this class would be our potential collaborators.

Of these 39 students, 23 (59\%) were male and 16 (41\%) female. As expected for this level of schooling, the students were in the 15 to 17 -year-old age range, with some of them returning to school after an interruption of their studies. This data is relevant, as it signals the importance of this type of school in the rural context, seeing that this institution is configured as an incentive for campo youths to finish their studies, without needing to abandon their communities.

4. The Journey brings together Lecampo students, several of their teachers, monitors, and coordinators. It foresees didactic-pedagogical works developed by the students of the course, in the rural schools of the region, presenting integrative proposals in partnership with the teachers of these institutions, favoring their insertion in the professional school universe. In addition to these school activities, the Journey enables greater integration with the community, through visits to the various non-school learning spaces, such as associations, unions, artistic and cultural institutions, among others. 
The EFA reaches at least seven cities and twenty-six rural communities. With respect to the class we researched, only 04 of the 39 students resided in the urban area of the cities reached by the EFA. These localities are found on the Araçuai microregion, belonging to the Jequitinhonba mesoregion.

Another important piece of data relates to the origin of the students' motivation to attend the EFA. Most stated they were referred by relatives (60\% answered that they have siblings, cousins, and uncles as EFA students or alumni) or friends. We found that there was a legitimacy in these referrals and network of close relations as an element in the outreach, which contributes to the EFA becoming an educational space in which long-lasting and familial ties are formed or reinforced. Another interesting datum is the fact that $56 \%$ of the students recorded that, along with seeking technical training (indicated as motivation by $77 \%$ of the respondents), the EFA's good reputation was a primary factor in them deciding to go through the selection process.

It should be noted that $85 \%$ of the respondents indicated that they enjoy studying at the EFA and that they adapted well to the alternating boarding school format, even though $56 \%$ of the respondents reported some challenges faced in the adaptation week.

On the use of new digital technology, data shows that the students access the internet frequently, either at home, at school, in lan bouses, or through wi-fi access from third parties (neighbors, commercial establishments, among others). The data also shows the great potential of social media (especially Facebook, Instagram, and WhatsApp, the most mentioned in the questionnaires) as a factor in socialization among these young people, seeing as more than $80 \%$ of the subjects reported maintaining profiles in one of more of these social networks. This same percentage of students also stated they were regular cellphone users, too.

In this regard, an analytical comment is suitable. During our visit to the EFA in June 2017, for the fulfillment of another field study, with the objective to also observe the process of video production by the diverse groups of students, we came across an emblematic scene in the auditorium in which the meetings were held. The following photo records this event. 


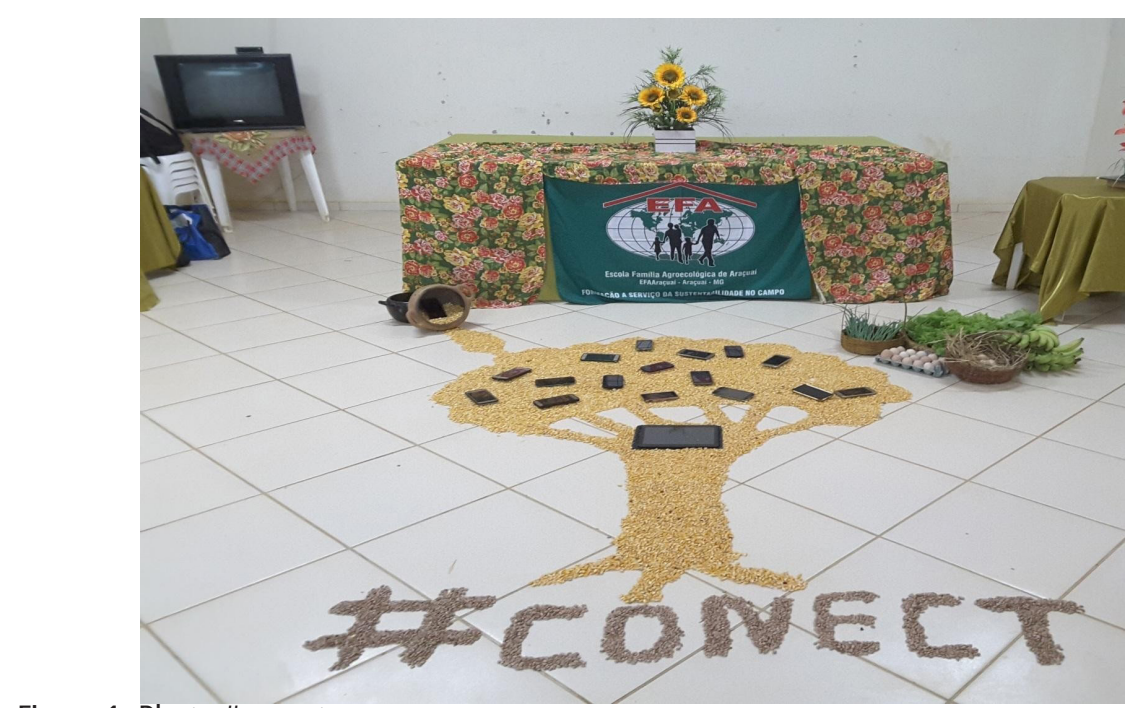

Figure 1. Photo \#conect

Source: research archive

On the floor in front of the table (covered by a chita towel, a fabric normally associated with campo identity, which is also used to make clothes and other artifacts), on top of which is a vase containing sunflowers which takes us back to campo education symbology (i.e., the sunflower signifies movement and seed abundancy), and a flag with the symbol of the EFA and the identification of the Araçuaí Family Agroecological School. Here we have an installation idealized and produced by the students, which speaks volumes about their imagination and the way they wish to be seen, starting from their expectations about the nature of the research conducted in that space. Composed, in its central part, by the illustration of a tree composed of corn grains, while the tree's fruits are the students' own cellphones and a tablet; above the tree top we can find, to the (viewer's) left, a clay bowl from which the corn grains originate, containing another tablet in its interior; to the right, we find an arrangement composed of agricultural foods, such as eggs, vegetables, and bananas; touching the tree's roots, we find the word connect spelled using beans, preceded by the basbtag symbol. The clay bowl functions in a manner similar to a cornucopia, Greek-roman mythical symbol of fertility and abundance. In the case of the installation, the bowl produces so many corn grains that it creates the image of the tree, representative of nature, together with the arrangement of agricultural foods, and as for the 'technological seed' simulated by the tablet, producing fruit in the form of digital artifacts. 
This symbolic combination brings characteristic elements from the campo, such as its natural products, and elements from its scenery, and way of life, together with other elements associated with technology, especially new media. This union isn't a simple juxtaposition of elements, but, rather, an organic connection. The representation of the tree made up of seeds that 'sprout' from a bowl, and having technological artifacts as fruits, indicates a vital cycle, a symbiotic process. The basbtag located below the roots and written with beans not only confirms the intended approximation, but also, due to its very nature and function, seeks to highlight the representation, indexing it explicitly to third parties.

As such, the installation synthesized the particularity of digital technology's insertion into the campo, especially, in the case of the students, during the course of their appropriation, starting with the interactions made possible by EFA itself and the contact with the research team.

\section{THE VIDEO PRODUCTION PROCESS}

Our second trip to the Araçuaí Family Agroecological School, carried out in June 2016, had as an objective the delivery of research specific tablets for the students and the launch of a video production proposal. These videos would be produced by student teams created for this objective through a video analysis and production argumentation workshop.

To reach these objectives, care was taken to avoid adopting an information transmission logic, which Santos speaks of (2010), and in this manner establish an effective mode of communication with the campo students involved in the research project. The meaning of communication in the activities proposed to the youths gained an idea present in the etymology of the word, described as a process that comes from a social negotiation, loaded with "pragmatic concerns and symbolic values" (SANTOS, 2010, p.587). The video production workshop began from this perspective, and sought group adhesion to the proposed task.

Initially, the exhibition of short videos selected by the researchers was carried out with the objective to collectively analyze aspects of its construction, such as the creation of a script or plan that contemplated the theme; the selection of images/ sceneries/contexts to be made; the possible texts - interviews, testimonials, songs, poems, etc. - which could be connected to the images; the definition of narration styles; the choice of social actors who could represent the chosen theme; among other aspects. Afterwards, another selected video-narratives available on YouTube were shown, so that aspects connected to the treatment of the interviews and 
testimonials in the productions would come to light through the example. In a second visit, other videos were shown, produced by undergrad students from the Curso de Licenciatura em Educação do Campo, in a discipline about cinema, so that the youths could identify elements of their composition in a continuation of our collective discussion about the videos' verbal and visual language construction modes.

After this analytic phase, the young people formed work groups for the elaboration of a theme for the videos to be produced, guided by the following questions: (1) As for the choice of a theme: what would be an interesting theme in relation to the communities, for the creation of a video? (b) As for the choice of figures/people representative of the communities: which people in the community could be interviewed or approached to give testimonials about the chosen theme(s)? (c) As for producing an early interview script: which questions could these people be asked? Or what would we like for them to speak about? (d) As for the location and other film elements: where could the video be filmed? Which images - of the surroundings, of documents, of objects, of sceneries - could also appear during the interview or testimonial? Each group received a theme that was filled as the result of a discussion guided by the questions. The table below summarizes the result of the groups' discussion about the video production work that began at that time (see Table 1).

Table 1. Themes for video production

\begin{tabular}{|c|c|c|c|}
\hline Groups & Initial Theme & Choice justification & Elements to be explored \\
\hline 1 & $\begin{array}{l}\text { "Lagoão Plateau and } \\
\text { its peerless riches" }\end{array}$ & $\begin{array}{l}\text { "We chose this theme because } \\
\text { the Lagoão Plateau contributes } \\
\text { to local development, being } \\
\text { considered a cradle of the } \\
\text { cultural and environmental } \\
\text { riches." }\end{array}$ & $\begin{array}{l}\text { "People who are important to } \\
\text { the community and who have } \\
\text { historical knowledge about the } \\
\text { location. People who live in the } \\
\text { location. Pequi, brooms, native } \\
\text { and medicinal plants." }\end{array}$ \\
\hline 2 & $\begin{array}{l}\text { "History of the } \\
\text { Tesouras and Palmital } \\
\text { communities" }\end{array}$ & $\begin{array}{l}\text { "To deepen our knowledge } \\
\text { about our community." }\end{array}$ & $\begin{array}{l}\text { "Manoel and José because they } \\
\text { have a larger body of knowledge } \\
\text { about the communities. Themain } \\
\text { changes that occurred during } \\
\text { the community's existence. } \\
\text { At the residences of the } \\
\text { interviewees. The church signs. } \\
\text { Pictures from before and after." }\end{array}$ \\
\hline
\end{tabular}




\begin{tabular}{|c|c|c|c|}
\hline 3 & $\begin{array}{c}\text { "Leisure in the Gravatá } \\
\text { and Lagoa dos Patos } \\
\text { communities" }\end{array}$ & $\begin{array}{l}\text { "Parties, football: the parties } \\
\text { are important to preserve the } \\
\text { culture. Football is a form of } \\
\text { entertainment." }\end{array}$ & $\begin{array}{l}\text { "Party participants, organizers. } \\
\text { When football appeared in the } \\
\text { communities. The importance } \\
\text { of football. What is needed to } \\
\text { play football. Who participates } \\
\text { in football. How the parties are } \\
\text { organized. Their importance, } \\
\text { how they started, when they } \\
\text { occur. Football fields, at the } \\
\text { party house and the church. Ball, } \\
\text { cleats, shin-guards and nets. } \\
\text { Bow, flag, mast, fire, fireworks, } \\
\text { players. Video and photo." }\end{array}$ \\
\hline 4 & $\begin{array}{l}\text { "The Araçuaí river } \\
\text { through the years" }\end{array}$ & $\begin{array}{l}\text { "Why it was through him [the } \\
\text { river] that the largest city in } \\
\text { the Jequitinhonha Valley came } \\
\text { to be" }\end{array}$ & $\begin{array}{l}\text { "Visits to group members' } \\
\text { communities." }\end{array}$ \\
\hline 5 & "Alagadiço community" & $\begin{array}{l}\text { "Because it portrays the } \\
\text { history of the community, } \\
\text { which has a reality that should } \\
\text { be known by all." }\end{array}$ & $\begin{array}{l}\text { "Community histories and } \\
\text { stories. João, because he is best } \\
\text { informed about community } \\
\text { history and facts. Jequitinhonha } \\
\text { River, the abandoned mansion, } \\
\text { the indigenous villaga. } \\
\text { Indigenous objects. Pictures of } \\
\text { the old school and the village." }\end{array}$ \\
\hline
\end{tabular}

Source: research data

According to our community orientation for the video project, the groups opted for some facet of the communities' histories. Three groups decided to develop a video that would register their community's importance, relying on the experience of older inhabitants. One group manifested the desire to focus on the Araçuaí River, a choice also related to rescuing local history, while another group chose to speak about soccer, a sport that in the rural communities has a strong socialization factor. Following this initial work, the thematic decisions were resumed in interview sessions with the groups during our subsequent visits. Focal group interview methodology was adopted to engage students in describing their video production process and in some cases showed changes to what had initially been predicted. In these sessions, aside from the thematic questions, action planning procedures were discussed. Speaking, reading, and writing elements related to this task were identified in these group interlocution processes, such as the creation of scripts or lack thereof in predominantly oral elaboration procedures in 
argumentative debates. The dynamic established in the focal groups, also recorded with audiovisual resources for data purposes, made visible reading, writing, and oral practices involved in the complex video production process, which aren't seen when analyzing only the final product.

The discussions that pervade the video planning go against studies which place "rural youth" as attuned only to urban cultural patterns in school. As shown above, considering their thematic choices indicated in the first work plans, the young people adhered to a proposal to rescue and value the rural identities of their originating communities. The questions connected to the use of technology for video production were focalized in a later stage of the project, which required a workshop with the objective to discuss editing strategies. At this stage in the production, the groups - some more advanced than others - had collected the raw material - such as images, long testimonials and interviews - which demanded efforts to produce a shareable video. For this it was necessary to discuss simultaneities between written and oral language, the relationship between languages (image, visual, oral, written), as well as what perhaps had been most difficult for the groups, exercising the selective capacity to reach the established maximum duration time of 10 minutes. Not all were able to pass the previous phase to finalization. However, it was observed how the selections strongly maintained the rural dimension of the proposals in the videos that were finalized, either in the frames devoid of any media appeal to which young people are exposed daily, or in the interview clips, without the use of elements that could falsify the identity of the people living in the countryside (e.g. The interviews were recorded mainly in domestic environments, maintaining an atmosphere of intimacy and authenticity in the spaces). During the collaborative work, the students exchanged their editing challenges and got help from EFA staff, including teacher and monitors.

In her study on video production processes in rural contexts, Pyles (2016) indicates that its analysis is "a working definition of rural media literacy, a literacy practice that respects the knowledge, identities, and values of local, rural areas and people expressed through rural youths' media literacy productions" (PYLES, 2016, p.1). Pyles provides an initial defense that, in the possible contrast between urban and rural, the discussion should surpass a definition that prioritizes geographic and demographic aspects and should be based on a discussion that involves cultural understanding. However, Pyles also recognizes that this cultural understanding tends to present 'rurality' framed from the perspective of an external and simplified gaze, and, not uncommonly, reinforcing stereotypes about rural populations and places. Rural youth is more 'visible' than its urban counterpart. In Pyles' opening, 
the testimonial of a young woman highlights this sense of belonging, alerting to the impossibility of invisibility, seeing as all know her and know she represents a community.

Pyles (2016) wanted to understand how rural youth expresses itself, especially through literacy practices that use visual media and how these medias can be considered distinctly 'rural'. In his/her study, a group of young people ranging from 14 to 22 years old was documented during their activities in a video production program that involved their community and which was offered by a non-government organization that developed various local culture divulgation works by means of theatrical groups and radio programs, for example.

Studies about literacy practices in rural communities tend not to focus on how the rural context can be a significant informing literacy factor. As a rule, the stereotype that paints rural populations as illiterate and non-technological prevails. In relation to video production, some studies indicate a tendency for the videos produced by the youths to be more about the communities or about themselves as members of their communities, rather than about issues of strongly individualized perspectives. However, 'rurality' as an identificatory label can be confirmed or rejected by participants. In her study, Pyles analyses two important instances: (a) decisions about the documentary's theme and (b) decisions about the documentary's editing. The videos analyzed by the author reveal methods of creating a "viable identity" (p.7) as well as tensions between moving closer or further from the community, seeing as meeting certain community expectations was at stake.

\section{ANALYSIS OF PRODUCED VIDEOS AND FRAGMENTS}

In November 2017, the five videos produced by the students were presented in a collective session in a display at the EFA itself. Some were finalized while others were displayed even though they were found in a provisional state. The videos were given the titles: "Lagoão Plateau and its peerless riches", "History of the Tesouras and Palmital communities", "Leisure in the communities and cacbaça production", "The Araçuaí river through the years", and "Alagadiço community" (see Table 1). 
Table 2. Synopsis of produced videos

\begin{tabular}{|c|c|}
\hline Group & Synopsis \\
\hline Lagoão & $\begin{array}{l}5: 48 \mathrm{~min} \text {. The video narrates the story } \\
\text { of the Lagoão Plateau, the Araçuaí/ } \\
\mathrm{MG} \text { community, and the inhabitants' } \\
\text { fight to defend part of their land } \\
\text { purchases illegally by a company from } \\
\text { São Paulo. }\end{array}$ \\
\hline History & $\begin{array}{l}\text { 5:05min. The video tells the } \\
\text { history of the Tesouras and Palmital } \\
\text { communities, where a drought a } \\
\text { few years ago caused livestock and } \\
\text { plantation losses, school closings, } \\
\text { and the exodus of most of their } \\
\text { inhabitants. According to the } \\
\text { interviewees, nowadays, despite the } \\
\text { implementation of artesian wells, } \\
\text { emigrated families haven't returned } \\
\text { to their originating communities } \\
\text { which, sadly, become "ghost towns". }\end{array}$ \\
\hline Leisure & $\begin{array}{l}\text { 23:57min. The video shows some } \\
\text { of the Araçuai/MG regions rural } \\
\text { communities' leisure activities, such } \\
\text { as football matches, youth gatherings } \\
\text { and religious parties. }\end{array}$ \\
\hline
\end{tabular}




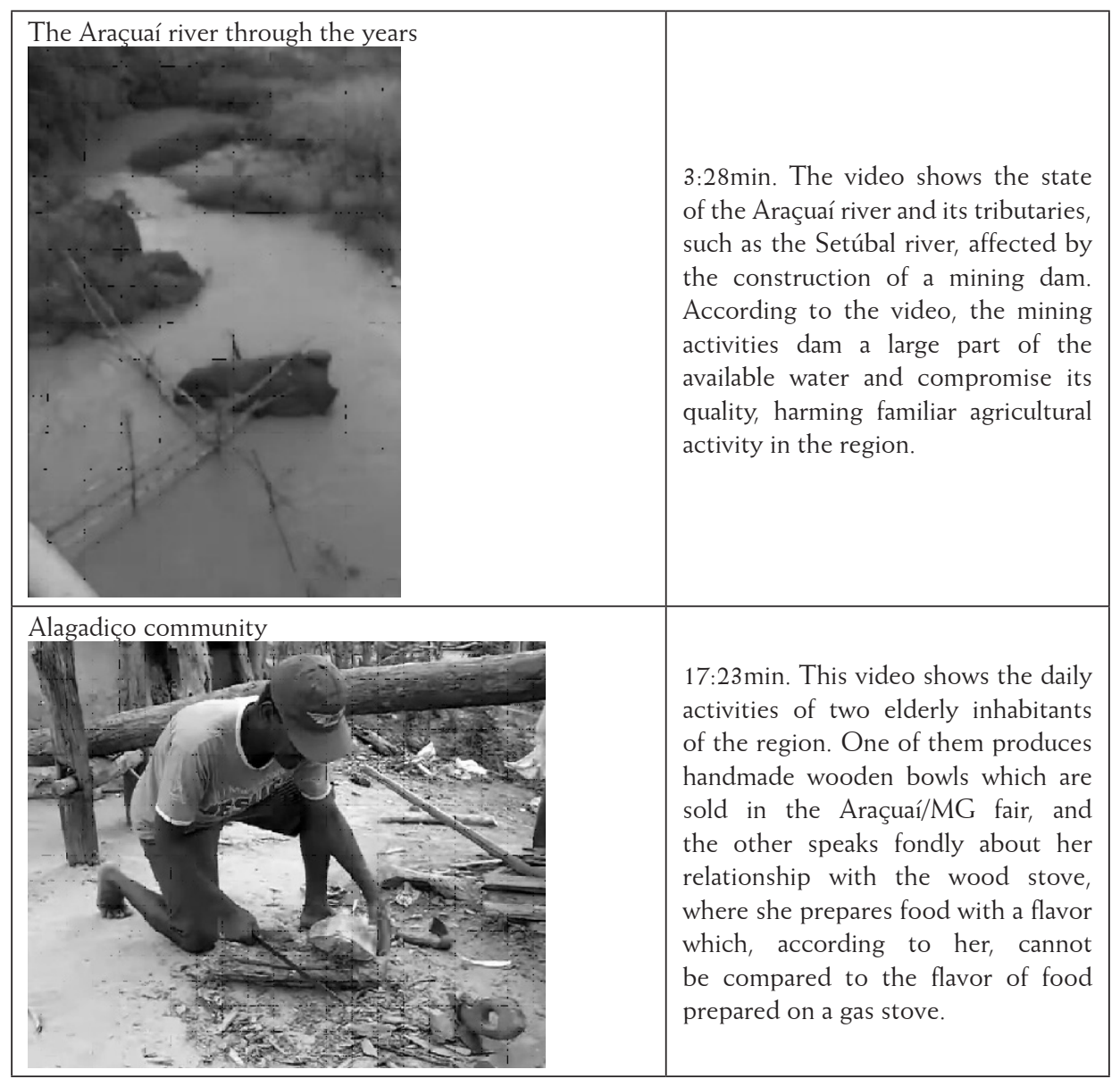

Source: research data

Many of the videos focused on the appreciation of the communities' histories, as stated by the students themselves:

We rescued a bit of the communities' histories. Maybe this history ends and when we portray this history in the video it'll go passing, and passing, and maybe people will never forget the importance of that community and that location. [excerpt from the speech of an EFA student about the video's objective]

In relation to the themes, a preference to take on matters involving a possible tension between tradition and innovation was verified. This tension could be found in the presence of aspects that involved cultural and economical practices considered somewhat obsolete nowadays and, therefore, subject to potentially vanishing, 
while topics related to youths' sociability are also being altered, such as sporting event organization. There was a strong tendency to polarize themes in a temporal dimension that places 'yesterday' and 'today', without, however, establishing an absolute linear valuation concerning these two dimensions. At times, the positive perspective moved towards 'yesterday', highlighting values and practices maintained as guarantors of the identity constitution; at other times towards 'today', especially as far as improved conditions offered by new technologies. Such variation was dependent on the insertion conditions of each work group in the universe of their community practices, or even the sociocultural context in which the community itself was located. Furthermore, the region's characterization as a place in which young people face many social and economical struggles was striking.

The documentary nature of the narratives indicated a preference for interviews, supported by scripts and open questions. It was also noted that the choice of informants/interviewees was based on the students' social relations. Aside from this aspect, the diversity of strategies and results deriving from the choices of interviewees with distinct profiles is highlighted. The community leader, who was one of the founders of the EFA and grandfather of one of the group's participants, for example, was a highlight in a report prioritized in one of the videos. In others, men and women were selected to tell their stories, trades, and current living conditions. Reverence towards the older community members is highlighted when noted that the interviewees were predominantly adults, retainers of knowledge about local history. This caused the youths, authors of the visual narratives, to be surprised with certain local practices, especially professional practices of a more artisanal character. This knowledge brought legitimacy and authority to knowledge built in the communities, making it possible to emphasize the values aggregated to the school and non-school knowledge in the debates that followed the videos' presentation.

Bringing some of Zezé's speech is extremely important. It was neat to know that it [Lagoão Plateau] is a place of great importance to the school, which faces so many challenges, when he talks about the fires, the use of natural resources in an aggressive manner... it was important for each of us to bring this material, to show to our classmates and to you, who don't know the place. [Excerpt from an EFA student's testimonial.]

Regarding the formal video production process and the mastery of composition techniques, there was a varied degree of product completion, with maintenance and/or alteration of initial proposals, and the justification of production strategies that took as a reference, for example, the presence or lack of a script for image capturing purposes. 
(...) because the soiree was gonna be here, right? And [EFA's director] asked for us to focus on that. So we made another chronogram. But the theme didn't change much, it's still about the community's traditions (...). So I filmed with my cellphone (...) I went early and came back late, made the movie from the beginning to the end of the bowl-making process, but it didn't all save, that's why there wasn't a proper closing. [Excerpt from an EFA student's testimonial.]

The cutting and editing procedures of the recording material, including an off-screen narrator, soundtracks that compose the narratives, as well as subtitles, proved to be difficult elements for the students. On the other hand, setting aside technical difficulties in the video production process, the need for a collective elaboration for the authorial process made accessing revealing shared literacy negotiation strategies possible. (BARTON $;$ HAMILTON; 2000). During the video production challenge proposed to them, the youths mobilized complex reading and writing strategies that were hidden when unable to access the continuous process of exchanges between them in different production stages.

\section{FINAL CONSIDERATIONS}

Following the video production process undertaken by the campo youth students of the Araçuaí Family Agricultural School - reinforced the idea that the campo cannot be reduced to homogeneous forms of sociability where reading and writing practices aren't evident in their diverse technologies. The role of orality permeated by reading and writing practices is emphasized in our data, be it in the production of arguments and clearly defined shifts in the discussion groups, or in the selection of community members spoken language for the audiovisual text. The traditional view of 'community' itself, understood from the perspective of identity and location, should be problematized when confronted with new technological possibilities. In this sense, the use or non-use of digital technologies isn't sustained by a differentiation factor between campo youths and urban youths.

For the campo youths, access to the internet makes human interaction possible and provides an opportunity to feel like part of the network of information and exchanges it creates. In this aspect, internet access also contributes to diminishing frontiers between what constitutes urban and rural, seeing as these spaces become accessible via the internet, in other words, campo youths can access urban 'realities' using the internet, and vice-versa. This also makes it possible to question the preconceived "isolation" of the rural areas which ends up creating a distorted image of its inhabitants. We observed that, even though some young people didn't have a computer or internet access at home, the use of cellphones, 
wi-fi (from the school, from neighbors, from commercial establishments) and the computer lab at EFA favors these students' access to the internet.

The familiarity these students have with new technologies was also made clear when we encountered our research collaborator's preference for using their own cellphones instead of the tablets given to them for image capture. Aside from the fact that most students possessed smartphones - which favors an important independence in capturing images for the videos - they are certainly also much more familiar with the available media-making tools on their cellphones, which also prove to be more dynamic and rich in resources and applications (for capturing and editing images, sharing image files and footage between members) which could have contributed to the production of their videos.

We conclude our analysis with the need for certain considerations. The main one refers to the postulate of not labeling rural communities as social spaces where literacy practices are absent, and therefore the reiteration of a perspective of deficit in relation to desirable literacies in terms of dominant practices, especially those that presents the values of schooling as elements that produce some visibility for the actions of reading, writing and speaking in situations that require greater language monitoring. On the other hand, the induction practices for video production also made it possible to challenge the commonsense idea that young people would be unconditionally digital connected.

Pondering digital use, for example, demands indicating that some of the students produce videos as a commonplace activity, far from school practices which evidence mastery of certain mechanisms which weren't broached in the school context. In this way, it may be urgent that the school also augment its literacy concepts and expectations, not only pluralizing practices, but making more visible those that aren't evident and especially incorporating them as a constitutive element of their teaching and learning project.

\section{$\overline{\text { REFERENCES }}$}

BARTON, D.; HAMILTON, M. (2000). Literacy practices. In: BARTON, D.; HAMILTON, M.; IVANIC, R. Situated literacies. Reading and writing in context. London: Routledge, p.7-15.

CORBETT, M.; DONEHOWER, K. (2017). Rural Literacies: Toward Social Cartography. Journal of Research in Rural Education, 32(5), 1-13. 
GREEN, B. (2013). Literacy, ruarality, education. A partial mapping. In: GREEN, B.; CORBERTT, M. Retbinking rural literacies. Transnational perspectives. New York: Palgrave Macmillan, p. 17-34.

HEATH, S. B.; STREET, B. V. (2008). On Ethnography. Columbia: Teachers College Columbia.

JONES, K.; MARTIN-JONES, M.; BHATT, A. (2012) A construção de uma abordagem crítica, dialógica para a pesquisa sobre o letramento multilingue: diários de participantes e entrevistas. In: MAGALHÃES, I. (Org.). Discursos e práticas de letramento. Campinas, SP: Mercado de Letras, p. 111-158.

LEÃO, G.; ANTUNES-ROCHA, M. I. (2015). Juventudes no/do campo: questões para um debate. In: Juventudes do campo. Belo Horizonte: Autêntica.

MOLINA, Mônica C. Cultivando princípios, conceitos e práticas da Educação do Campo. In: Presença Pedagógica, Belo Horizonte, v. 15, n. 88, p. 30-36, jul/ago. 2009.

PYLES, D. G. (2016). Rural media literacy: Youth documentary videomaking as a rural literacy practice. Journal of Research in Rural Education, 31 (7), 1-15.

SANTOS, M. O lugar e o cotidiano. (2010) In: SANTOS, M.; MENESES, M. P. (orgs.). Epistemologias do sul. São Paulo: Cortez.

STREET, B. (2014). Letramentos sociais: abordagens críticas do letramento no desenvolvimento, na etnografia e na educação. São Paulo: Parábola Editorial.

Recebido: 23/09/2019

Aceito: 2/02/2020

Publicado: 4/03/2020 